Hydrol. Earth Syst. Sci., 15, 11-20, 2011

www.hydrol-earth-syst-sci.net/15/11/2011/

doi:10.5194/hess-15-11-2011

(c) Author(s) 2011. CC Attribution 3.0 License.

\title{
Hydrological characterization of watersheds in the Blue Nile Basin, Ethiopia
}

\author{
S. G. Gebrehiwot ${ }^{1,4}$, U. Ilstedt ${ }^{2}$, A. I. Gärdenas ${ }^{3}$, and K. Bishop ${ }^{1,5}$ \\ ${ }^{1}$ Department of Aquatic Sciences and Assessment, Swedish University of Agricultural Sciences, P.O. Box 7050, 75007 \\ Uppsala, Sweden \\ ${ }^{2}$ Department of Forest Ecology and Management, Swedish University of Agricultural Sciences, 90183 Umeå, Sweden \\ ${ }^{3}$ Department of Soil and Environment, Swedish University of Agricultural Sciences, P.O. Box 7001, 75007 Uppsala, Sweden \\ ${ }^{4}$ Department of Geography and Environmental Studies, Addis Ababa University, P.O. Box 1176, Addis Ababa, Ethiopia \\ ${ }^{5}$ Department of Earth Sciences, Villavägen 16, Uppsala University, 75236, Uppsala, Sweden
}

Received: 31 May 2010 - Published in Hydrol. Earth Syst. Sci. Discuss.: 2 July 2010

Revised: 5 December 2010 - Accepted: 12 December 2010 - Published: 3 January 2011

\begin{abstract}
Thirty-two watersheds $\left(31-4350 \mathrm{~km}^{2}\right)$, in the Blue Nile Basin, Ethiopia, were hydrologically characterized with data from a study of water and land resources by the US Department of Interior, Bureau of Reclamation (USBR) published in 1964. The USBR document contains data on flow, topography, geology, soil type, and land use for the period 1959 to 1963 . The aim of the study was to identify watershed variables best explaining the variation in the hydrological regime, with a special focus on low flows. Moreover, this study aimed to identify variables that may be susceptible to management policies for developing and securing water resources in dry periods. Principal Component Analysis (PCA) and Partial Least Square (PLS) were used to analyze the relationship between five hydrologic response variables (total flow, high flow, low flow, runoff coefficient, low flow index) and 30 potential explanatory watershed variables. The explanatory watershed variables were classified into three groups: land use, climate and topography as well as geology and soil type. Each of the three groups had almost equal influence on the variation in hydrologic variables $\left(R^{2}\right.$ values ranging from 0.3 to 0.4$)$. Specific variables from within each of the three groups of explanatory variables were better in explaining the variation. Low flow and low flow index were positively correlated to land use types woodland, dense wet forest and savannah grassland, whereas grazing
\end{abstract}

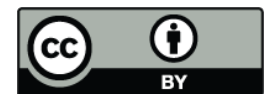

Correspondence to: S. G. Gebrehiwot (solomon.gebreyohannis@vatten.slu.se) land and bush land were negatively correlated. We concluded that extra care for preserving low flow should be taken on tuffs/basalts which comprise $52 \%$ of the Blue Nile Basin. Land use management plans should recognize that woodland, dense wet forest and savannah grassland can promote higher low flows, while grazing land diminishes low flows.

\section{Introduction}

The response of watersheds to rainfall cannot yet be predicted with certainty due to the complexity of hydrology (Sivapalan, 2005). General classes of watershed variables attributed to the differences in hydrological response to rainfall are soil properties, geology, anthropogenic activities, relief, size, local climate and vegetation cover (Black, 1997; Uhlenbrook, 2003; Sivapalan, 2005). Some watershed variables are more important in ways that are specific to different watersheds and scales. One way to advance the predictive power of watershed hydrology is to characterize watersheds based on the most influential variables (McDonnell et al., 2007), as this provides a basis for planning of land management issues for developing and securing water resources (Saxena et al., 2000). Moreover, characterization of watersheds with reference to hydrological response complements process-oriented modeling (Yadav et al., 2007), as the difficulty in parameterization of differences in watershed variables is one of the major obstacles to the progress of process-oriented hydrological modeling (Hauhs and Lange, 2008).

Published by Copernicus Publications on behalf of the European Geosciences Union. 
The characterization of hydrological response of watersheds is crucial in areas such as the Blue Nile where the well-being of the majority of the population depends on the ability to manage water scarcity to produce food on a subsistence basis. Although the average annual precipitation is $1800 \mathrm{~mm} \mathrm{yr}^{-1}$ (Ministry of Water Resources, 1998), the local population can still suffer from water shortages during the dry season. Therefore, land management is necessary for reducing the negative consequences of seasonal water shortages. However, other factors influence water availability besides those that can be "managed", such as topography, geology and local climate. Management plans, and expectations for success need to be based on an understanding of the full range of factors controlling watershed response to rainfall, in addition to those that management can influence.

The watersheds in the Blue Nile Basin were characterized and hydrologically homogenous units were delineated for the purpose of flood frequency analysis using Hoskin L-moments (Abebe, 2007). Abebe (2007) found five generalized regional flood frequency curves for the Basin. In addition, Adane and Foerch (2006) discuss the characterization of watersheds for predicting the base flow index in Wabi Shebele, a $1.2 \times 10^{5} \mathrm{~km}^{2}$ Basin in Ethiopia that adjoins the Blue Nile Basin to the Southeast and flows to the East of the country. Catchment size, stream density, climate index, hypsometric integral, Normalized Difference Vegetation Index (NDVI) and geological parameters were evaluated for their usefulness in predicting the base flow index for this basin. Adane and Foerch (2006) concluded that the strongest correlation was between lower dry season flows and higher NDVI. Given the transboundary importance of the Blue Nile, there is scope for a more complete characterization of the watersheds of the Blue Nile Basin, especially regarding the critical low flow period.

Spatial characterization of differences in the hydrological regime of the Blue Nile watersheds requires data. Systematic and spatially extensive flow data were collected on the Blue Nile from 1959 to 1963 at the time of the building of the Aswan Dam on the Nile. The investigation of land and water resources was initiated by the Ethiopian government in cooperation with the US Department of Interior, Bureau of Reclamation (USBR). Hydrological data were collected from 59 gauge stations during the period 1959 to 1963 . Monthly flow data along with descriptions of soil, geology, land use and topography were published for 35 stations covering the four year period (US Department of Interior, 1964). We applied multivariate methods to these published data in order to characterize the hydrological response of the region (high flows, annual flows and low flows) in terms of catchment geology, topography, land use, soil and climate.

The main aim of this study was to determine the watershed variables that best described the variability in hydrological regime, in particular the low flow, in the Blue Nile Basin. The second aim was to identify variables that may be susceptible to management policies for developing and securing water resources in the dry periods. Consideration is given to potential differences between contemporary land use patterns and soil conditions compared to those at the time of the USBR study.

\section{Materials and methods}

\subsection{Site description of the Blue Nile Basin}

The $2 \times 10^{5} \mathrm{~km}^{2}$ Blue Nile Basin contributes about $60 \%$ of the Nile's flow at Aswan, Egypt, even though the Blue Nile comprises only about $8 \%$ of the total Nile catchment area. In the period 1960-1964, rainfall in the Blue Nile ranged from 880 to $2070 \mathrm{~mm}$ per annum. The watersheds of the Basin have a range of sizes, slopes, climatic patterns, topography, drainage patterns, geological formations, soils, vegetation cover and anthropogenic activities. There are three broad topographical divisions: the highland plateau, steep slopes adjoining the plateau that tilt to the west and the western low lands with gentler topography comprising the remainder of the Basin. The steep slopes and the plateaus extend from $1500 \mathrm{~m}$ to ca $4000 \mathrm{~m}$ above sea level and combined cover about $65 \%$ of the Basin area. In addition, the Basin is characterized by three different geological formations: the crystalline basement exposed over $32 \%$ of the area, sedimentary formations covering about $11 \%$ in the deep valleys of major southern tributaries, and volcanic formations covering about $52 \%$ of the area in the North, Central and Eastern part of the Basin (Ministry of Water Resources, 1998). The dominant soil texture of the Basin is clay with the special type of shrinking and expanding clay, called Vertisol, covering about $15 \%$ of the Basin.

\subsection{The study watersheds}

Between 1958 and 1963, USBR and the Ethiopian Government studied the land and water resources of the Blue Nile Basin. In 1964, USBR published "Land and Water Resources of the Blue Nile" in seven volumes, comprising one main report and six appendixes: Plans and estimates, Hydrology, Geology, Land classification, Power, Agriculture and Economics (US Department of Interior, 1964).

The USBR document contains monthly discharge data from 35 watersheds for the period 1959 to 1963. All 35 of these watersheds were included in the study from the beginning. Three watersheds were subsequently excluded: two because they were comprised of other watersheds in the data set, and one because of insufficient flow data. For the 32 watersheds, 5 different hydrological variables and 30 different watershed variables were extracted from the main report and appendices for Hydrology, Geology, and Land classification (i.e. from four volumes out of the seven). The extracted variables are presented in Fig. 1 and Table 1. The terminology in Table 1 is used in subsequent figures and tables. 

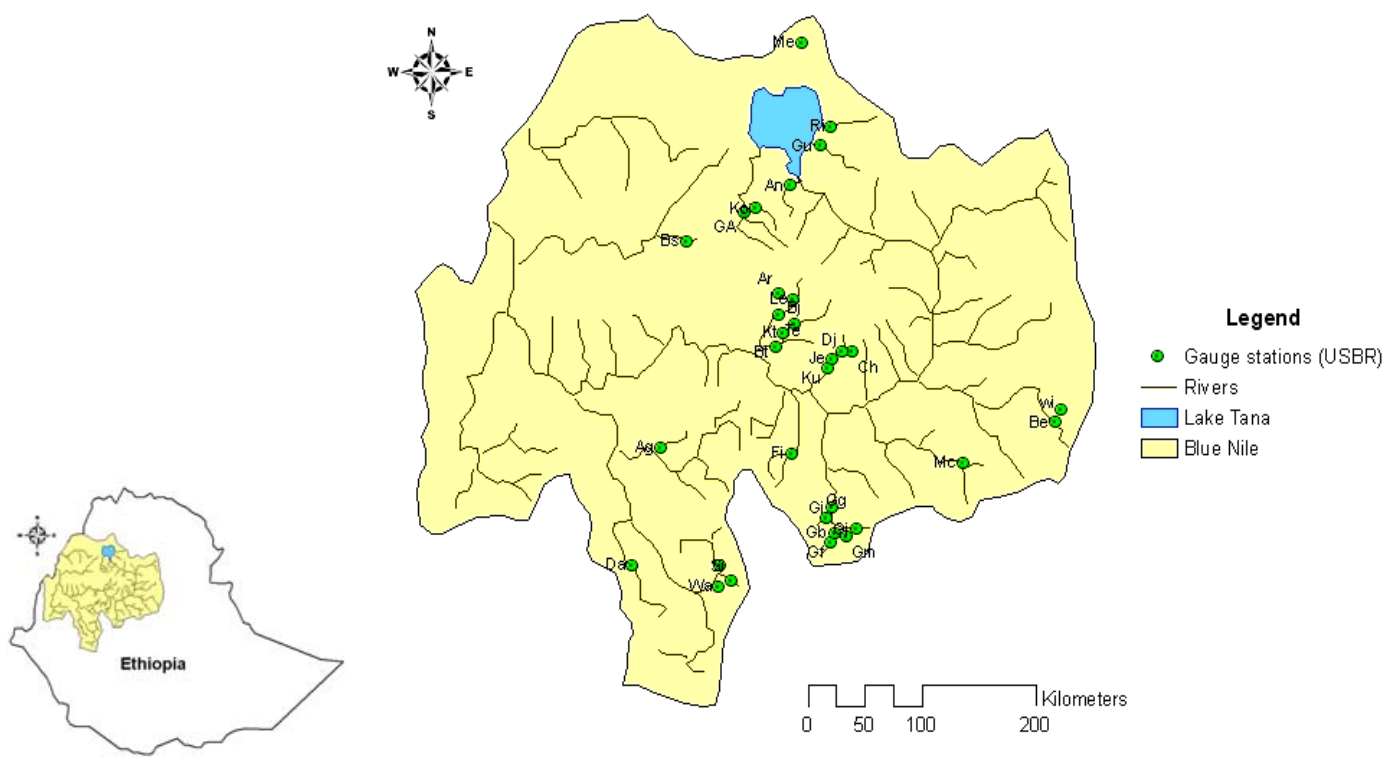

Fig. 1. Location of USBR hydrological stations in the Blue Nile Basin included in this study ( 32 watersheds). See Table 1 for the watershed names associated with each abbreviation on the map.

\subsection{Hydrological variables}

The five hydrologic variables used in the study were: (i) average annual flow (Qt $\left[\mathrm{mm} \mathrm{yr}^{-1}\right]$ ), (ii) minimum monthly flow hitherto called low flow (Q1 [ $\left.\left.\mathrm{mm} \mathrm{yr}^{-1}\right]\right)$, (iii) maximum monthly flow hitherto called high flow ( $\mathrm{Qh}\left[\mathrm{mm} \mathrm{yr}^{-1}\right]$ ), (iv) low flow index (LFI), which is the ratio of low flow to the total flow for the year and (v) runoff coefficient (C) which is the ratio of total flow to rainfall. Flow data were transformed from the SI units (monthly cubic meters) to $\mathrm{mm}$, based on respective watershed areas. High and low flows, low flow index, and runoff coefficient were computed from the monthly flow data for the four years published in the USBR report.

Discharge was based on continuous stage measurements at control reaches. These stage measurements were made using automatic chart recorders and backed up by manual staff gauge readings made daily at 0600 and 1800 . The rating curve for each control reach was constructed from repeated flow measurements during the four-year study period using current meters deployed either from bridges or aerial cableways.

\subsection{Watershed variables}

The climatic data, i.e. rainfall $\left(P\left[\mathrm{~mm} \mathrm{yr}^{-1}\right]\right)$ and temperature $\left(T\left[{ }^{\circ} \mathrm{C} \mathrm{day}^{-1}\right]\right)$ were collected by the National Meteorological Service Agency of Ethiopia. Data from thirty-nine meteorological stations were available, and the closest one to each watershed was used in further analysis of that watershed. Potential evaporation (ET $\left.\left[\mathrm{mm} \mathrm{day}^{-1}\right]\right)$ was extracted from the USBR documentation. The geographical information taken from the main report of the USBR document in- cludes latitude (Lat [degree-decimal]) and longitude (Long [degree-decimal])) of the center of each watershed, area of the watersheds (Area $\left[\mathrm{km}^{2}\right]$ ), average elevation $(\mathrm{El}[\mathrm{m}])$ and average slope class (Slope [\%]). All variables were summarized from text and map information in the USBR document.

The hydrologic, climatic, relief, and geographical data are all continuous variables, so-called numerical descriptors. The geology, soil and land use types were discontinuous, socalled categorical descriptors. The different classes within the groups of these variables are dependent on each other, as the sum of the coverage of the different classes within a group is $100 \%$. Fuzzy coding for assigning dummy variables (Upton and Cook, 2006) was used to quantify these nominal descriptors. For example, four different geological classes were identified: alluvials (Allu), sandstones/limestones (S/L stones), tuffs/basalts (Tu/Ba) and metamorphic rocks (Meta). The four fractions of the geological classes total to one $(100 \%)$ for each watershed. The same procedure was used for soil and land use types.

Nine different soil types were considered. These included: shallow leptosols (Lepto), soils with a very high content of coarse materials; cambisols (Cambi) characterized by a cambic B horizon or an umbric A horizon; arenosols (Areno) with albic, argillic, cambic or oxic horizon; luvisols (Luvi) highly basic and with an argillic horizon; alisols (Ali), acidic and infertile soils; eutric-vertisols (EutV), clay rich soils; regosols (Rego), soils formed on unconsolidated material except for recent alluvial deposits; acrisols (Acri), soils with an argillic B horizon and less basic; and wetlands (Wet), soils having voids filled with water.

Nine different land use classes were selected. These included: cultivated land (CU), arable land for seasonal crop 
production; dense wet forest (DWF), a humid highland forest where annual rainfall exceeds $1500 \mathrm{~mm}$; dense dry forest (DDF), a montane forest where annual rainfall ranges from 500-1500 mm; open woodland (OWL), sparsely distributed trees and shrubs with dominant grassland; woodland (WL), a drought resistant vegetation type dominated by trees and shrubs; savannah grassland (SGL), lowland grasslands up to $1.3 \mathrm{~m}$ in height and undisturbed by humans; grazing land (GL), land designated for open grazing under human management; riverine forest (RF), continuous forest cover along river banks where the height of trees could be greater than 10 $\mathrm{m}$; and bush land (BL), vegetation includes shrubs, succulents and grasses with shallow degraded soil. Any temporal changes in soil and land use properties due to natural and human activities within the watersheds were assumed insignificant due to the short period (1959-1963) being examined for spatial differences in hydrology.

\subsection{Statistical analysis}

Multivariate analysis was performed on the observations from the 32 watersheds using five hydrological and 30 watershed variables (Table 1). Multivariate analysis is capable of handling both categorical and continuous types of data in the same analysis (Eriksson et al., 2001; Gärdenas, 1998; and Eriksson et al., 1995).

\subsubsection{Data processing}

Two specific steps were undertaken to enable the simultaneous use of both categorical and continuous data types in multivariate analyses. The first step was transforming the categorical data, which sums to one, with a special log-transformation as recommended by Wang et al. (2010), called centered logratio transformation. The centered logratio transformation is defined as

$t=\log \left(\frac{\chi_{j}}{\left(\prod_{i=1}^{p} x_{i}\right)^{1 / p}}\right) ;$

where $t$ is the transformed variable value, $x_{j}$ is the original value, $x_{i}$ is the number of parts (portions) in the unit one, and the total number of parts are $p$. This transformation linearizes the data and resolves the problem of proportions adding to unit one. The second step was centering and scaling of the variances to control variability caused by the different data types with different units. Each variable in the geology, soil and land use classes was centered and scaled in order to generate unit variance and control the differences in scales as recommended by Eriksson et al. (2001).

Principal Component Analysis (PCA) and Partial Least Square (PLS) were used to explore multivariate relationships between the variables using SIMCA 12.0.1 (UMETRICS, 2009). PCA and PLS find new and independent latent variables (principal components) that maximize the explained variance. For each analysis, PCA or PLS, four components were considered to get the total explained variation. The variation explained by these components is expressed by $R^{2}$ (Eriksson et al., 2001), which is a measure of fit of the variables to the components.

First step PCA and PLS analyses were run using all available explanatory watershed variables in order to identify the watershed variables that were significant. The confidenceinterval of the loadings for each of the four components was determined by jackknifing (Eriksson et al., 2001). Loadings express the importance and direction (positive or negative) of variables in explaining the variance of each component (Eriksson et al., 2001). If a specific variable loading is higher than the $90 \%$ confidence interval of the components loading, the variable was considered significant. Finally, the significant variables were used in the final PCA and PLS analyses.

\subsubsection{Principal Component Analysis (PCA)}

PCA was conducted on the significant hydrological and watershed variables to show how they correlated to or deviated from each other. PCA maximizes the explained variance among all variables (Eriksson et al., 2001). In PCA, the two types of variables, hydrologic and watershed, were treated together. The PCA runs were summarized in plots of the first two-components.

\subsubsection{Partial Least Squares (PLS)}

The PLS identifies explanatory $(x)$ variables responsible for changes in response ( $y$ ) variables (Eriksson et al., 2001). The hydrologic variables are response $(y)$ variables, and the watershed variables are explanatory $(x)$ variables in this analysis. Before running the PLS the hydrological variables were divided into two; the total/high flow regime (Qt, $\mathrm{Qh}$ and $\mathrm{C}$ ) and the low flow regime (Q1 and LFI). Then two PLS models were run; one for the total/high flow regime, the second for the low flow regime. In addition to considering all the explanatory watershed $(x)$ variables, watershed variables were grouped into three conceptual groups: land use, climate and topography as well as geology and soil type. This was to see if some of the groups of watershed variables were more important for explaining the variation of the hydrological response variables.

\section{Results}

\subsection{Significant and insignificant watershed variables}

In the first step of the multivariate analyses approximately $60 \%$ of all watershed variables were significant at the $90 \%$ confidence level in explaining the variation between the watersheds with respect to the hydrological regime (Table 2). The least number of significant variables were observed in the PLS model for total/high flow regime. Only 11 out of the 
Table 1. Watersheds and their respective variables, as extracted from the USBR document (US Department of Interior, 1964) ${ }^{\mathrm{a}}$.

\begin{tabular}{|c|c|c|c|c|c|c|c|c|c|c|c|c|c|c|c|c|c|c|c|}
\hline \multicolumn{2}{|l|}{ Watershed } & \multirow[b]{2}{*}{$\mathrm{Qt}$} & \multirow[b]{2}{*}{ Q1 } & \multirow[b]{2}{*}{ Qh } & \multirow[b]{2}{*}{ LFI } & \multirow[b]{2}{*}{$C$} & \multirow[b]{2}{*}{$P$} & \multirow[b]{2}{*}{$T$} & \multirow[b]{2}{*}{ ET } & \multirow[b]{2}{*}{$\mathrm{El}$} & \multirow[b]{2}{*}{ Slope } & \multirow[b]{2}{*}{ Allu } & \multirow[b]{2}{*}{$\begin{array}{r}\mathrm{S} / \mathrm{L} \\
\text { stone }\end{array}$} & \multirow[b]{2}{*}{$\mathrm{Tu} / \mathrm{Ba}$} & \multirow[b]{2}{*}{ Meta } & \multirow[b]{2}{*}{ GL } & \multirow[b]{2}{*}{$\mathrm{CU}$} & \multirow[b]{2}{*}{ OWL } & \multirow[b]{2}{*}{ DWF } \\
\hline name & code & & & & & & & & & & & & & & & & & & \\
\hline Gilgel Abbay & GA & 981.5 & 3.2 & 355.5 & 0.0032 & 0.63 & 1562 & 17.0 & 3.4 & 2250 & 12.5 & 0 & 0 & 1 & 0 & 0.2 & 0.5 & 0.1 & 0 \\
\hline Koga & Ko & 578.7 & 5.0 & 224.3 & 0.0086 & 0.37 & 1562 & 17.0 & 3.4 & 2250 & 7.5 & 0.1 & 0 & 0.9 & 0 & 0.2 & 0.6 & 0 & 0 \\
\hline Gummera & $\mathrm{Gu}$ & 747.6 & 4.1 & 380.3 & 0.0055 & 0.51 & 1460 & 17.0 & 3.4 & 2900 & 7.5 & 0.1 & 0 & 0.9 & 0 & 0.1 & 0.5 & 0.2 & 0 \\
\hline Megetch & $\mathrm{Me}$ & 240.9 & 0.5 & 99.1 & 0.0020 & 0.21 & 1170 & 20.4 & 3.8 & 2250 & 22.5 & 0.05 & 0 & 0.95 & 0 & 0.1 & 0.8 & 0.1 & 0 \\
\hline Angereb & An & 374.8 & 2.9 & 168.0 & 0.0078 & 0.30 & 1264 & 17.0 & 3.4 & 2000 & 12.5 & 0.1 & 0 & 0.9 & 0 & 0.1 & 0.7 & 0.05 & 0 \\
\hline Ribb & $\mathrm{Ri}$ & 235.9 & 0.2 & 228.4 & 0.0010 & 0.16 & 1460 & 17.0 & 3.4 & 2500 & 10 & 0.15 & 0.05 & 0.8 & 0 & 0.1 & 0.5 & 0.2 & 0 \\
\hline Wizer & Wi & 711.7 & 0.2 & 355.8 & 0.0002 & 0.80 & 887 & 14.2 & 3.3 & 2800 & 5 & 0 & 0 & 1 & 0 & 0.2 & 0.5 & 0 & 0 \\
\hline Beressa & $\mathrm{Be}$ & 509.4 & 1.2 & 240.0 & 0.0024 & 0.57 & 887 & 14.2 & 3.3 & 2800 & 15 & 0 & 0 & 1 & 0 & 0.2 & 0.5 & 0 & 0 \\
\hline Muger_chancho & $\mathrm{Mc}$ & 289.2 & 0.9 & 137.9 & 0.0030 & 0.24 & 1192 & 13.3 & 3.1 & 2800 & 5 & 0.2 & 0 & 0.8 & 0 & 0.3 & 0.3 & 0 & 0 \\
\hline Guder_Jibat & $\mathrm{Gj}$ & 648.4 & 2.5 & 170.3 & 0.0039 & 0.48 & 1352 & 13.3 & 3.1 & 2800 & 7.5 & 0.2 & 0 & 0.8 & 0 & 0.1 & 0.4 & 0 & 0 \\
\hline Guder_Guder & $\mathrm{Gg}$ & 792.5 & 1.8 & 318.4 & 0.0023 & 0.59 & 1352 & 13.3 & 3.1 & 2800 & 7.5 & 0.2 & 0 & 0.8 & 0 & 0.15 & 0.45 & 0 & 0 \\
\hline Guder_Melke & $\mathrm{Gm}$ & 510.0 & 2.4 & 167.3 & 0.0047 & 0.38 & 1352 & 13.3 & 3.1 & 2800 & 5 & 0.2 & 0 & 0.8 & 0 & 0.15 & 0.45 & 0 & 0 \\
\hline Guder_Fato & Gf & 613.2 & 1.8 & 218.1 & 0.0030 & 0.45 & 1352 & 13.3 & 3.1 & 2800 & 5 & 0.2 & 0 & 0.8 & 0 & 0.05 & 0.45 & 0 & 0 \\
\hline Guder_Idris & $\mathrm{Gi}$ & 866.7 & 6.6 & 370.3 & 0.0076 & 0.64 & 1352 & 13.3 & 3.1 & 2800 & 5 & 0.2 & 0 & 0.8 & 0 & 0.2 & 0.5 & 0 & 0 \\
\hline Guder_Bello & $\mathrm{Gb}$ & 819.1 & 1.8 & 294.3 & 0.0022 & 0.61 & 1352 & 13.3 & 3.1 & 2800 & 12.5 & 0.2 & 0 & 0.8 & 0 & 0.2 & 0.5 & 0 & 0 \\
\hline Fincha & $\mathrm{Fi}$ & 330.3 & 3.1 & 89.1 & 0.0095 & 0.32 & 1025 & 22.5 & 3.9 & 1750 & 22.5 & 0.45 & 0.05 & 0.5 & 0 & 0.1 & 0.3 & 0 & 0 \\
\hline Beles & Bs & 313.4 & 0.7 & 139.8 & 0.0023 & 0.32 & 971 & 23.9 & 4.0 & 750 & 5 & 0 & 0 & 0.75 & 0.25 & 0 & 0.2 & 0.2 & 0 \\
\hline Birr_Jiga & $\mathrm{Bj}$ & 668.3 & 0.2 & 364.0 & 0.0004 & 0.49 & 1355 & 19.2 & 3.5 & 2750 & 22.5 & 0 & 0 & 1 & 0 & 0.2 & 0.4 & 0.1 & 0 \\
\hline Birr_Temcha & $\mathrm{Bt}$ & 1291.0 & 2.5 & 537.2 & 0.0019 & 0.79 & 1644 & 19.2 & 3.5 & 2750 & 18.5 & 0 & 0 & 1 & 0 & 0.3 & 0.45 & 0 & 0 \\
\hline Temim & $\mathrm{Te}$ & 827.4 & 0.3 & 396.7 & 0.0003 & 0.61 & 1355 & 19.2 & 3.5 & 2750 & 18.5 & 0 & 0 & 1 & 0 & 0.15 & 0.45 & 0 & 0 \\
\hline Arera & $\mathrm{Ar}$ & 477.9 & 2.9 & 223.9 & 0.0061 & 0.35 & 1355 & 19.2 & 3.5 & 2750 & 7.5 & 0 & 0 & 1 & 0 & 0.15 & 0.45 & 0 & 0 \\
\hline Leza & $\mathrm{Le}$ & 415.2 & 2.1 & 252.8 & 0.0052 & 0.31 & 1355 & 19.2 & 3.5 & 2750 & 18.5 & 0 & 0 & 1 & 0 & 0.1 & 0.4 & 0.2 & 0 \\
\hline Ketchem & $\mathrm{Kt}$ & 1107.3 & 0.9 & 455.6 & 0.0008 & 0.82 & 1355 & 19.2 & 3.5 & 2750 & 18.5 & 0 & 0 & 1 & 0 & 0.2 & 0.4 & 0.1 & 0 \\
\hline Dabana & $\mathrm{Da}$ & 590.6 & 2.6 & 213.4 & 0.0044 & 0.29 & 2071 & 22.6 & 3.8 & 1000 & 5 & 0 & 0 & 1 & 0 & 0 & 0.3 & 0.2 & 0.2 \\
\hline Angar & $\mathrm{Ag}$ & 611.0 & 3.0 & 191.6 & 0.0049 & 0.30 & 2071 & 22.6 & 3.8 & 1000 & 7.5 & 0 & 0.25 & 0.25 & 0.5 & 0.1 & 0.3 & 0.2 & 0.1 \\
\hline Chemoga & $\mathrm{Ch}$ & 716.7 & 1.7 & 294.8 & 0.0023 & 0.53 & 1355 & 15.7 & 3.4 & 2750 & 18.5 & 0.15 & 0 & 0.85 & 0 & 0.2 & 0.4 & 0 & 0 \\
\hline Djilil & $\mathrm{Dj}$ & 480.5 & 1.9 & 217.4 & 0.0039 & 0.35 & 1355 & 15.7 & 3.4 & 2750 & 18.5 & 0.15 & 0 & 0.85 & 0 & 0.1 & 0.6 & 0 & 0 \\
\hline Kulch & $\mathrm{Ku}$ & 1157.8 & 4.4 & 574.8 & 0.0038 & 0.70 & 1655 & 15.7 & 3.4 & 2750 & 18.5 & 0.15 & 0 & 0.85 & 0 & 0.2 & 0.5 & 0 & 0 \\
\hline Jedeb & $\mathrm{Je}$ & 1100.2 & 3.8 & 517.8 & 0.0035 & 0.35 & 1355 & 15.7 & 3.4 & 2750 & 18.5 & 0.15 & 0 & 0.85 & 0 & 0.2 & 0.4 & 0 & 0 \\
\hline Fettaru & $\mathrm{Fe}$ & 1725.6 & 7.0 & 676.1 & 0.0041 & 0.70 & 2071 & 17.9 & 3.3 & 1750 & 10 & 0 & 0 & 1 & 0 & 0.1 & 0.4 & 0.1 & 0.2 \\
\hline Sifa & $\mathrm{Si}$ & 754.1 & 3.6 & 177.9 & 0.0047 & 0.81 & 2071 & 17.9 & 3.3 & 1750 & 12.5 & 0 & 0 & 1 & 0 & 0.2 & 0.3 & 0.1 & 0.3 \\
\hline Wama & Wa & 604.1 & 2.9 & 194.9 & 0.0048 & 0.83 & 2071 & 17.9 & 3.3 & 1750 & 12.5 & 0 & 0 & 1 & 0 & 0.2 & 0.3 & 0.1 & 0.3 \\
\hline
\end{tabular}

30 were significant. Almost half of the explanatory watershed variables were significant in explaining the variation in the low flow regime.

\subsection{Principal Component Analysis (PCA)}

The total variation explained by the PCA with significant watershed variables in the first two components was $R^{2}=0.4$ (Fig. 2); and the total variation explained by four components was $R^{2}=0.6$. Low flows increased with increased rainfall, dense wet forest, riverine forest and alisols but decreased with more dense dry forest, bush land, alluvials, regosols, eutric-vertisols and cultivated land. The LFI, which normalizes the minimum flow to annual flow, was positively correlated to wetland and woodland, but was negatively correlated to average slope, grazing land and tuffs/basalts. Total flow, high flow and runoff coefficient increased with increment of tuffs/basalts and average slope, but decreased with the increment of wetland and woodland.

There were negative correlations between a number of explanatory variables, including those between grazing land and woodland; grazing land and wetland; bush land and dense wet forest; dense dry forest and dense wet forest; riverine forest and cultivated land. There were positive correlations between grazing land and tuffs/basalts; wetland and woodland; dense dry forest, bush land and cultivated land; as well as between dense wet forest and riverine forest.

\subsection{Partial Least Square (PLS)}

The variables explaining the variation and potential predictors of the total/high flow regime were grazing land, tuffs/basalts, rainfall, dense wet forest and leptosols (Table 2 and Fig. 3). The cumulative variation explained by the first two components was $R^{2}=0.5$ and the cumulative variation explained by four components was $R^{2}=0.6$.

Alluvials, luvisols, rainfall, savannah grassland, dense wet forest, tuffs/basalts, longitude and eutric-vertisols were significant for explaining the variation in the low flow regime (Q1 and LFI) (Fig. 3). The variability explained by the first two components was $R^{2}=0.4$ and the variability explained by four components was $R^{2}=0.6$.

In the PLS analysis, the hydrological variables (both total/high flow and low flow regimes) were positively 
Table 1. Continued.

\begin{tabular}{|c|c|c|c|c|c|c|c|c|c|c|c|c|c|c|c|c|c|c|}
\hline \multicolumn{2}{|l|}{ Watershed } & \multirow[b]{2}{*}{ DDF } & \multirow[b]{2}{*}{ SGL } & \multirow[b]{2}{*}{ WL } & \multirow[b]{2}{*}{ RF } & \multirow[b]{2}{*}{$\mathrm{BL}$} & \multirow[b]{2}{*}{ Lepto } & \multirow[b]{2}{*}{ Cambi } & \multirow[b]{2}{*}{ Areno } & \multirow[b]{2}{*}{ Luvi } & \multirow[b]{2}{*}{ Ali } & \multirow[b]{2}{*}{ EutV } & \multirow[b]{2}{*}{ Rego } & \multirow[b]{2}{*}{ Acri } & \multirow[b]{2}{*}{ Wet } & \multirow[b]{2}{*}{ Area } & \multirow[b]{2}{*}{ Long } & \multirow[b]{2}{*}{ Lat } \\
\hline name & code & & & & & & & & & & & & & & & & & \\
\hline Gilgel Abbay & GA & 0.1 & 0 & 0.05 & 0.05 & 0 & 0 & 0 & 0 & 0.8 & 0 & 0 & 0.2 & 0 & 0 & 1660 & 37.1 & 11.5 \\
\hline Megetch & $\mathrm{Me}$ & 0 & 0 & 0 & 0 & 0 & 1 & 0 & 0 & 0 & 0 & 0 & 0 & 0 & 0 & 519 & 37.5 & 12.7 \\
\hline Angereb & An & 0 & 0.1 & 0 & 0.05 & 0 & 0.9 & 0 & 0 & 0.1 & 0 & 0 & 0 & 0 & 0 & 660 & 37.6 & 11.5 \\
\hline Ribb & $\mathrm{Ri}$ & 0.2 & 0 & 0 & 0 & 0 & 0 & 0 & 0 & 0.2 & 0 & 0.8 & 0 & 0 & 0 & 1497 & 37.7 & 12.0 \\
\hline Muger_chancho & $\mathrm{Mc}$ & 0.3 & 0.1 & 0 & 0 & 0 & 0.1 & 0 & 0 & 0 & 0 & 0.8 & 0.1 & 0 & 0 & 606 & 38.7 & 9.3 \\
\hline Guder_Jibat & $\mathrm{Gj}$ & 0.3 & 0.1 & 0 & 0 & 0.1 & 0 & 0 & 0 & 0.3 & 0.5 & 0.2 & 0 & 0 & 0 & 143 & 37.9 & 9.0 \\
\hline Guder_Guder & $\mathrm{Gg}$ & 0.3 & 0 & 0 & 0 & 0.1 & 0 & 0 & 0 & 0.3 & 0.45 & 0.25 & 0 & 0 & 0 & 499 & 37.9 & 9.0 \\
\hline Guder_Melke & $\mathrm{Gm}$ & 0.3 & 0 & 0 & 0 & 0.1 & 0 & 0 & 0 & 0.35 & 0.5 & 0.15 & 0 & 0 & 0 & 80 & 37.9 & 8.9 \\
\hline Guder_Fato & Gf & 0.3 & 0 & 0 & 0 & 0.2 & 0 & 0 & 0 & 0.3 & 0.5 & 0.2 & 0 & 0 & 0 & 98 & 37.8 & 8.9 \\
\hline Guder_Idris & $\mathrm{Gi}$ & 0.25 & 0 & 0 & 0 & 0.05 & 0 & 0 & 0 & 0.3 & 0.45 & 0.25 & 0 & 0 & 0 & 76 & 37.9 & 9.0 \\
\hline Temim & $\mathrm{Te}$ & 0.2 & 0.1 & 0 & 0.1 & 0 & 0.1 & 0 & 0 & 0.2 & 0.4 & 0.2 & 0.1 & 0 & 0 & 108 & 37.4 & 10.7 \\
\hline Arera & $\mathrm{Ar}$ & 0.2 & 0.1 & 0 & 0.1 & 0 & 0.1 & 0.2 & 0 & 0.2 & 0 & 0.2 & 0.3 & 0 & 0 & 31 & 37.3 & 10.7 \\
\hline Leza & Le & 0.2 & 0 & 0 & 0.1 & 0 & 0.1 & 0 & 0 & 0.2 & 0.4 & 0.2 & 0.1 & 0 & 0 & 159 & 37.4 & 10.7 \\
\hline Ketchem & Kt & 0.1 & 0.1 & 0 & 0.1 & 0 & 0.1 & 0 & 0 & 0.2 & 0.7 & 0 & 0 & 0 & 0 & 183 & 37.6 & 10.6 \\
\hline Dabana & $\mathrm{Da}$ & 0.2 & 0 & 0 & 0.1 & 0 & 0.1 & 0 & 0 & 0 & 0.8 & 0 & 0 & 0.1 & 0 & 3080 & 36.3 & 8.4 \\
\hline Angar & $\mathrm{Ag}$ & 0.2 & 0 & 0 & 0.1 & 0 & 0 & 0 & 0 & 0 & 0.7 & 0 & 0 & 0.3 & 0 & 4350 & 36.4 & 9.4 \\
\hline Chemoga & $\mathrm{Ch}$ & 0.1 & 0 & 0.1 & 0.1 & 0.1 & 0 & 0.1 & 0 & 0 & 0.8 & 0.1 & 0 & 0 & 0 & 320 & 37.8 & 10.3 \\
\hline Djilil & $\mathrm{Dj}$ & 0.05 & 0.1 & 0 & 0.1 & 0.05 & 0 & 0 & 0 & 0 & 0.7 & 0.2 & 0.05 & 0 & 0.05 & 70 & 37.5 & 10.8 \\
\hline Kulch & $\mathrm{Ku}$ & 0.1 & 0.1 & 0 & 0.1 & 0 & 0.05 & 0 & 0 & 0 & 0.55 & 0.3 & 0.05 & 0 & 0.05 & 50 & 37.3 & 11.0 \\
\hline Jedeb & $\mathrm{Je}$ & 0.1 & 0 & 0 & 0.1 & 0.2 & 0 & 0.1 & 0 & 0 & 0.8 & 0.1 & 0 & 0 & 0 & 250 & 37.7 & 10.5 \\
\hline Fettaru & $\mathrm{Fe}$ & 0 & 0.2 & 0 & 0 & 0 & 0 & 0 & 0 & 0 & 0.7 & 0.3 & 0 & 0 & 0 & 200 & 36.7 & 9.1 \\
\hline Sifa & $\mathrm{Si}$ & 0 & 0.1 & 0 & 0 & 0 & 0 & 0 & 0 & 0 & 0.8 & 0.2 & 0 & 0 & 0 & 978 & 36.8 & 8.9 \\
\hline Wama & Wa & 0 & 0.1 & 0 & 0 & 0 & 0 & 0.1 & 0 & 0 & 0.8 & 0.1 & 0 & 0 & 0 & 764 & 36.6 & 8.9 \\
\hline
\end{tabular}

a Codes of the variables represent; Qt total flow ( $\mathrm{mm} \mathrm{yr}^{-1}$ ), Qh maximum flow ( $\mathrm{mm} \mathrm{yr}^{-1}$ ), Q1 minimum flow ( $\mathrm{mm} \mathrm{yr}{ }^{-1}$ ), LFI low flow index, $C$ runoff coefficient, $P$ rainfall $\left(\mathrm{mm} \mathrm{yr}^{-1}\right), T$ temperature $\left({ }^{\circ} \mathrm{C}\right.$ day $\left.^{-1}\right)$, ET evapotranspiration $\left(\mathrm{mm} \mathrm{day}^{-1}\right)$, El elevation $(\mathrm{m})$, slope average watershed slope $(\%)$, Tu/Ba tuffs and basalts, S/L stone sand/lime stone, Meta metamorphic rock, Allu Alluvial, GL grazing land, CU cultivated land, OWL open woodland, DWF dense wet forest, DDF dense dry forest, SGL savannah grassland, WL woodland, BL (degraded) bush land, RF riverine forest, Lepto leptosols, Cambi cambisols, Rego regosols, Areno arenosols, Acri acrisols, Ali alisols, EutV Eutric Vertisols, Luvi luvisols, Wet Wetland, Area watershed area $\left(\mathrm{km}^{2}\right)$, Long Longitude (degree-decimal), Lat Latitude (degree-decimal).

correlated to rainfall (Fig. 3). However, tuffs/basalts had contrasting relationships to the total/high and low flow regimes. This geological group was positively correlated to the total/high flow group and negatively correlated to the low flow group. A comparison of the groups of explanatory variables indicated that the geology and soil group explained $10 \%$ more variation and gave better predictions for the total/high flow group than the climate and topography or land use groups (Table 2). All three groups of variables (land use, climate and topography as well as geology and soil type) had an equal influence on variation and prediction of low flow regime (Table 2).

\section{Discussion}

Different watersheds have different properties that influence the flow regime. Knowledge of these different properties can help in planning action on variables susceptible to management measures. Thus, it is useful to classify watersheds within a region on the similarity and differences in hydrologic regimes. Hydrological science seeks to find a way of understanding the interconnection of hydrological processes at the watershed scale by characterizing watershed variables (Sivapalan, 2005). As part of this process, this study characterized the relationship of catchment variables to hydrologic variables through multivariate analysis in order to identify predictors of the hydrological regime in the Blue Nile Basin.

The PCA analysis explained $60 \%$ of the variation within the significant watershed and hydrologic variables. Of this explained variance, $70 \%$ was explained in the first two components. Each of the explanatory variables had plausible causal explanations for being either positively or negatively correlated to the total/high flow regime. Wetland and woodland were the main factors for reducing total/high flow regime. For variables positively correlated to the total/high 
Table 2. Influence of explanatory variables. The "Non-significant variables" were determined from the $90 \%$ confidence interval. "Group of variables" column shows the relation of groups of explanatory variables for explaining response variables (flow parameters), as summarized from PLS analysis. a,b

\begin{tabular}{|c|c|c|c|c|c|c|c|c|c|}
\hline & \multicolumn{3}{|c|}{ Non-significant variables } & \multicolumn{6}{|c|}{ Group of variables } \\
\hline & \multirow[b]{2}{*}{ PCA } & \multirow[b]{2}{*}{$\begin{array}{l}\text { PLS_total/ } \\
\text { high flow }\end{array}$} & \multirow[b]{2}{*}{$\begin{array}{l}\text { PLS_low } \\
\text { flow }\end{array}$} & \multicolumn{3}{|c|}{ Total/high flow regime } & \multicolumn{3}{|c|}{ Low flow regime } \\
\hline & & & & $\begin{array}{l}\text { Climate and } \\
\text { topography }\end{array}$ & $\begin{array}{l}\text { Geology and } \\
\text { soil }\end{array}$ & $\begin{array}{l}\text { Land } \\
\text { use }\end{array}$ & $\begin{array}{l}\text { Climate and } \\
\text { topography }\end{array}$ & $\begin{array}{l}\text { Geology and } \\
\text { soil }\end{array}$ & $\begin{array}{l}\text { Land } \\
\text { use }\end{array}$ \\
\hline & $\begin{array}{l}\text { S/L stone } \\
\text { SGL } \\
\text { Lepto } \\
\text { Cambi } \\
\text { Acri } \\
\text { Areno } \\
\text { Luvi } \\
\text { Lat }\end{array}$ & $\begin{array}{l}T \\
\text { Slope } \\
\text { Allu } \\
\text { S/L stone } \\
\text { CU } \\
\text { OWL } \\
\text { WL } \\
\text { DDF } \\
\text { SGL } \\
\text { RF } \\
\text { Acri } \\
\text { Areno } \\
\text { Luvi } \\
\text { Cambi } \\
\text { EutV } \\
\text { Rego } \\
\text { Wet } \\
\text { Long } \\
\text { Lat }\end{array}$ & $\begin{array}{l}\text { El } \\
\text { Slope } \\
\text { GL } \\
\text { CU } \\
\text { DDF } \\
\text { WL } \\
\text { RF } \\
\text { BL } \\
\text { Areno } \\
\text { Lepto } \\
\text { Cambi } \\
\text { Rego } \\
\text { Lat } \\
\text { Wet }\end{array}$ & $\begin{array}{l}+P \\
+\mathrm{El} \\
-\mathrm{ET} \\
- \text { Area }\end{array}$ & $\begin{array}{l}+ \text { Ali } \\
+\mathrm{Tu} / \mathrm{Ba} \\
\text {-Meta } \\
\text {-Lepto }\end{array}$ & $\begin{array}{l}+\mathrm{GL} \\
+\mathrm{DWF} \\
-\mathrm{BL}\end{array}$ & $\begin{array}{l}+P \\
-\mathrm{ET} \\
-\mathrm{T} \\
- \text { Area } \\
- \text { Long }\end{array}$ & $\begin{array}{l}\text { +S/L stone } \\
+\mathrm{Luvi} \\
+\mathrm{Allu} \\
-\mathrm{Tu} / \mathrm{Ba} \\
-\mathrm{Meta} \\
-\mathrm{Ali} \\
-\mathrm{Tu} / \mathrm{Ba} \\
-\mathrm{EutV}\end{array}$ & $\begin{array}{l}+ \text { SGL } \\
+ \text { DWF } \\
-\mathrm{OWL}\end{array}$ \\
\hline$R^{2}$ & & & & 0.3 & 0.4 & 0.3 & 0.3 & 0.3 & 0.3 \\
\hline
\end{tabular}

${ }^{a}$ Codes of the variables represent; $P$ rainfall $\left(\mathrm{mm} \mathrm{yr}^{-1}\right), T$ temperature $\left({ }^{\circ} \mathrm{C} \mathrm{day}{ }^{-1}\right)$, ET evapotranspiration $\left(\mathrm{mm} \mathrm{day}^{-1}\right)$, El elevation $(\mathrm{m})$, slope average watershed slope $(\%)$, Tu/Ba tuffs and basalts, S/L stone sand/lime stone, Meta metamorphic rock, Allu Alluvial, GL grazing land, CU cultivated land, OWL open woodland, DWF dense wet forest, DDF dense dry forest, SGL savannah grassland, WL woodland, BL (degraded) bush land, RF riverine forest, Lepto leptosols, Cambi cambisols, Rego regosols, Areno arenosols, Acri acrisols, Ali alisols, EutV Eutric Vertisols, Luvi luvisols, Wet Wetland, Area watershed area $\left(\mathrm{km}^{2}\right.$ ), Long Longitude (degree-decimal), Lat Latitude (degree-decimal).

b “+"sign indicates positive relationship between hydrologic response and explanatory watershed variables; “-” indicates an inverse relationship.

flow regime (average slope, tuffs/basalts and grazing land), high flows would increase and infiltration would decrease, thus decreasing groundwater storage. With variables negatively correlated to total/high flow (wetland and woodland), water would flow more slowly and the infiltration rate into soils would be higher, thus increasing the ability of the catchment to store water. Therefore, management for promoting water infiltration, such as grassland, could result in higher low flows. This result was in accordance with other studies, as summarized by Bruijnzeel (2004). However, inherent factors, such as tuffs/basalts and average slope, that cannot be changed by management need to be considered in water planning.

The major variables positively correlated with low flow (Q1 and LFI) were wetland, woodland, dense wet forest, rainfall, riverine forest and alisols. Grazing land, tuffs/basalts, average slope, bush land, regosols, eutric-vertisols, dense dry forest, cultivated land and alluvials negatively correlated to the low flow regime. These relationships are plausible in terms of catchment processes. Grazing and bush land are features of land degradation in the region (Demel and Tesfaye, 2002) which promotes rapid runoff so less of the rainy season precipitation is held in the soil. The reduction of low flow with the increment of slope and eutric-vertisols is probably related to rapid runoff in steep terrain and accentuated by vertisols being prone to cracking and rapid bypass flows (Dekker and Ritsema, 1996).

The summarized PLS results from different groups of explanatory variables indicated how much each group explained the hydrologic response variables and the relative importance of specific explanatory variables within each group. From the climate and topography group, rainfall was the single factor positively correlated with both total/high flow and low flow regimes. Longitude was negatively correlated with low flow regime, which indicated more low flow in the western watersheds than the eastern watersheds. The three groups of explanatory variables (climate and topography, geology and soil, and land use) have almost equal strength in 


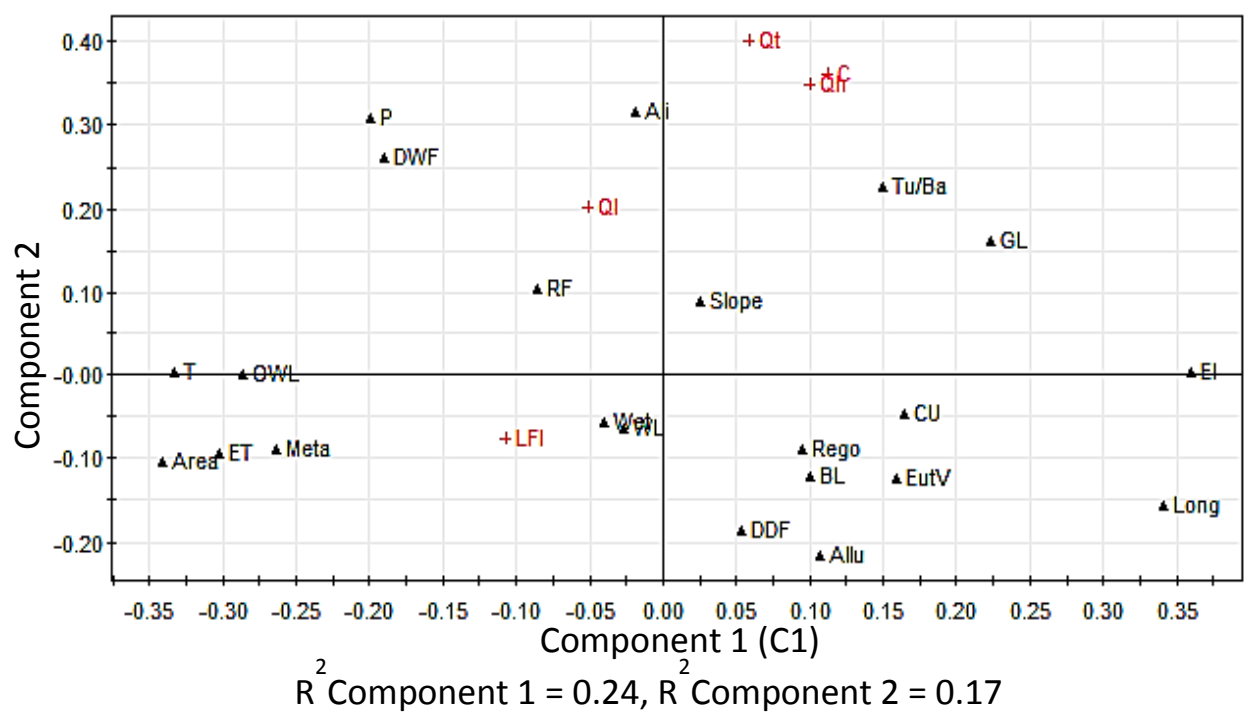

Fig. 2. PCA plot of the first two components for the hydrological and watershed variables. The hydrological variables are indicated with cross

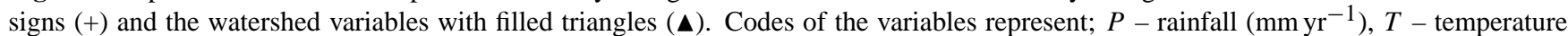
$\left({ }^{\circ} \mathrm{C} \mathrm{day}^{-1}\right), \mathrm{ET}$ - evapotranspiration $\left(\mathrm{mm} \mathrm{day}^{-1}\right), \mathrm{El}$ - elevation $(\mathrm{m})$, slope - average watershed slope (\%), Tu/Ba - tuffs and basalts, Meta metamorphic rock, Allu - Alluvial, GL - grazing land, CU - cultivated land, OWL - open woodland, DWF - dense wet forest, DDF - dense dry forest, WL - woodland, BL - (degraded) bush land, RF - riverine forest, Rego - regosols, Ali - ali sols, EutV - Eutric Vertisols, Wet Wetland, Area - watershed area $\left(\mathrm{km}^{2}\right)$, Long - Longitude (degree-decimal).

influencing the variability of flow regimes and in predicting flow regimes. The three groups separately explained less variation than selected variables from the whole range of explanatory variables. Based on the level of significance, a combination of variables of all groups doubled the variation being explained, as $R^{2}$ increased from 0.3 (Table 2) to 0.6 .

Dense wet forest, woodland and savannah grasslands were the three dominant land use features positively correlated to low flow regime. An improvement of low flow regime through woodland and grasslands is hypothesized for tropical areas by Bruijnzeel (2004) and Malmer et al. (2009). Such land use features in tropical areas increase the water retention of the soils. Land use such as grazing land and bush land are features indicating degradation of land resources (forests and soils) (Gete, 2000; Demel and Tesfaye, 2002). There was a negative correlation between grazing land and wetland or woodland and between riverine forest and dense wet forest (Fig. 2). This correlation should be considered in land management for improving dry season flows, especially if a "tradeoff" in land use management between woodland, savannah grassland, and wetland at one hand, and bush land and grazing land on the other hand is required. Woodland, savannah grassland and wetland ecosystems should be conserved for development and sustenance of low flow in the landscape, as low flows are a risk for current and future water availability (Smakhtin, 2001).

Low flow was positively correlated to rainfall (Figs. 2 and 3). Although rainfall is the source of wa- ter for every flow regime, some watershed variables have better ability to retain rainfall through soil infiltration rather than others that lose the rain to rapid runoff. Woodland, savannah grassland and wetland accompanied by deep soil and/or large catchment size were positively correlated to a catchment's ability to intercept and retain rainfall for later dry season flow. While we believe the general relationships found in these data from 1959-1963 are valid even 50 years later, the precise values of specific relationships may have changed. That is because land use properties have changed and soils have been degraded (Gete and Hurni, 2001). Although the data used in the study was older data, there was extensive spatial coverage and comparability of the sites, as they were all studied with similar methods within a single project. The fact that there was more extensive natural forest and grassland cover than at present (Bekele, 2003) is also of interest for conclusions on land use management. Although land use has changed and soil degradation is suspected, the results are considered generally applicable to water management practices that consider the influences of significant watershed variables. One potential problem with this study could be the non-stationarity of the climate, which particularly influences seasonal flow regimes. However, as the distinct wet/dry season regime remains in the region, the focus on low flows and high flows was still valid for current climatic conditions, as distinct high and low flow periods are still the dominant seasonal aspect of the flow regime. 

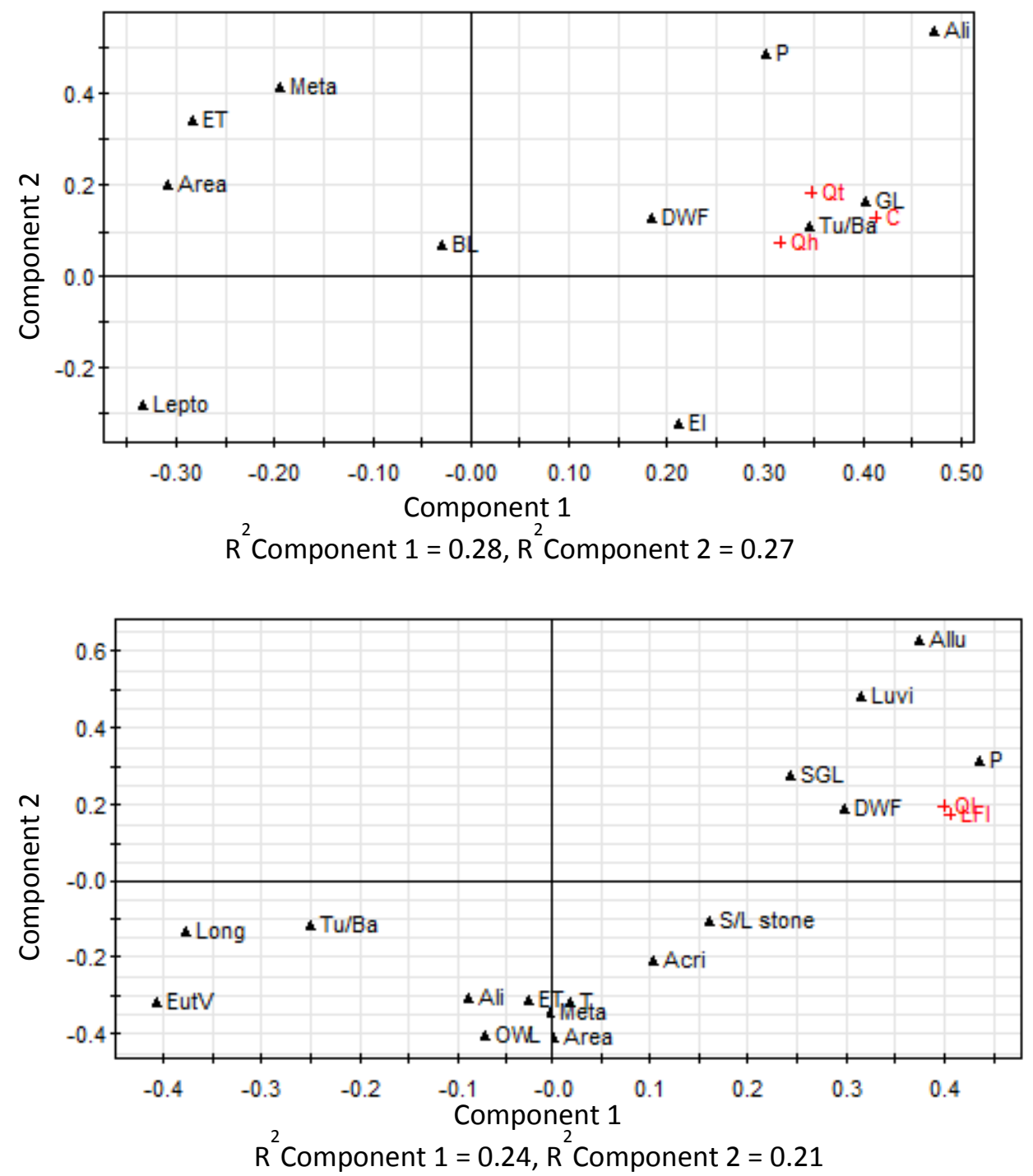

Fig. 3. PLS plots for total/high flow group (the first pane) and low flow group (second pane) with watershed (explanatory) variables that were significant at the $90 \%$ confidence level in prediction of the hydrological (response) variables. The hydrological variables were indicated with cross signs $(+)$ and the watershed variables with filled triangles $(\mathbf{\Lambda})$. Codes of the variables represent; $\left.P-\mathrm{rainfall}_{(\mathrm{mm}} \mathrm{yr}^{-1}\right)$, $\mathrm{T}-$ temperature $\left({ }^{\circ} \mathrm{C} \mathrm{day}^{-1}\right), \mathrm{ET}$ - evapotranspiration $\left(\mathrm{mm} \mathrm{day}^{-1}\right), \mathrm{El}$ - elevation $(\mathrm{m}), \mathrm{Tu} / \mathrm{Ba}$ - tuffs and basalts, S/L - stone sand/lime stone, Meta - metamorphic rock, Allu - Alluvial, GL - grazing land, OWL - open woodland, DWF - dense wet forest, SGL - savannah grassland, BL - (degraded) bush land, Lepto - leptosols, Acri - acrisols, Ali - alisols, EutV - Eutric Vertisols, Luvi - luvisols, Area - watershed area $\left(\mathrm{km}^{2}\right)$, Long - Longitude (degree-decimal).

\section{Conclusions}

A major goal of landscape management in the Blue Nile Basin is reduction of seasonal water shortages. Hydrological characterization provides a foundation for regionalization of watershed management in the Basin and can be especially useful for the management of ungauged watersheds. We used multivariate analysis to make a hydrological characterization, and this method proved useful in ways that may be applicable to other basins and/or time periods.
The analysis of spatially comprehensive data from the Blue Nile Basin collected between 1959 and 1963 provides empirical evidence of relevance for ongoing debates about whether some land use types, such as dense wet forest, woodland, wetland and savannah grassland, can promote higher low flow. We conclude that for sustaining water availability in dry periods, conservation of woodland, savannah grassland and wetland is important, whereas more grazing land and bush land could exacerbate water shortages during the dry season. 
Factors influenced by land management, such as extent of dense forest or woodland or grassland, can enhance the low flow regime. However, inherent factors such as topography, geology and local climate influence water availability besides those that can be "managed". This study highlighted how low flows can be generally lower in areas with volcanic soils, such as tuffs/basalts, which cover half of the Basin. Management plans and expectations for success in these plans need to be based on an understanding of the full range of factors controlling watershed response to rainfall, in addition to the factors management can influence. Map information, such as relief and soil type are thus useful in identifying where low flow will be a problem for local communities. Although this may be obvious, it is undocumented, and this documentation could serve as the basis for aiding calibration of hydrological models for management purposes. When attempting to identify human impacts on flow regime by land use/land cover, the impacts of inherent factors such as geology and local climate need to be distinguished, as management plans cannot influence these.

Acknowledgements. This paper was produced as a part of the research project funded by SIDA (Swedish International Development Agency): securing dry season flow in the Blue Nile Basin: how much forest helps as the climate changes. The authors are grateful to Martyn Futter for his advice on specific steps in the application of the transformation for the categorical data.

Edited by: M. Gebremichael

\section{References}

Abebe, S.: Identification and delineation of hydrological homogeneous regions - the case of Blue Nile River Basin, MSc Thesis, ArbaMinch University, Ethiopia, 2007.

Adane, A. and Foerch, G.: Catchment characterization as predictors of baseflow index (BFI) in Wabi Shebele river Basin, East Africa, Conference on International Agricultural Research for Development, University of Bonn, Germany, 11-13 October, 2006.

Bekele, M.: Forest property rights, the role of the state, and institutional exigency: the Ethiopian Experience PhD Thesis, Swedish University of Agricultural Sciences, Uppsala, Sweden, 2003.

Black, P. E.: Watershed functions, J. Am. Water Resour. As., 33(1), 1-11, 1997.

Bruijnzeel, L. A.: Hydrological functions of tropical forests: not seeing the soil for the trees?, Agriculture, Ecosystems and Environment, 104, 185-228, 2004.

Demel, T. and Tesfaye, B.: State of Forests and Forestry Research in Ethiopia. Indicators and Tools for Restoration and Sustainable Management of Forests in East Africa, I-TOO working paper No. 1, Addis Ababa, Ethiopia, 2002.

Dekker, L. W. and Ritsema, C. J.: Preferential flow paths in a water repellent clay soil with grass cover, Water Resources, 32(5), 1239-1249, 1996.

Eriksson, L., Johansson, E., Kettaneh-Wold, N., and Wold, S.: Multi- and Megavariate Data Analysis: Principles and Applications, UMETRICS AB, Umeå, Sweden, 2001.
Eriksson, L., Hermens, J. L. M., Johansson, E., Verhaar, H. J. M., and Wold, S.: Multivariate analysis of aquatic toxicity data with PLS, Aquat. Sci., 57(3), 217-241, 1995.

Gärdenas, A.: Soil organic matter in European forest floors in relation to stand characteristics and environmental factors, Scand. J. Forest Res., 13, 274-283, 1998.

Gete, Z.: Landscape dynamics and soil erosion process modelling in the Northwestern Ethiopian highlands, PhD Thesis, African Studies Series A16, Geographica Bernensia, Berne, Switzerland, 2000.

Gete, Z. and Hurni, H.: Implications of land use and land cover dynamics for mountain resource degradation in the Northwestern Ethiopian highlands, Mt. Res. Dev., 21(2), 184-191, 2001.

Hauhs, M. and Lange, H.: Classification of runoff in headwater catchments: A physical problem?, Geography Compass, 2(1), 235-254, 2008.

Malmer, A., Murdiyarso, D., Bruijnzeel, L. A., (Sampurno) and Ilstedt, U.: Carbon sequestration in tropical forests and water: a critical look at the basis for commonly used generalizations, Global Change Biology, Blackwell Publishing Ltd, 2009.

McDonnell, J. J., Sivapalan, M., Vache, K., Dunn, S., Grant, G., Haggerty, R., Hinz, C., Hooper, R., Kirchner, J., Roderick, M. L., Selker, J., and Weiler, M.: Moving beyond heterogeneity and process complexity: a new vision for watershed hydrology, Water Resour. Res., 43, 1-6, 2007.

Ministry of Water Resources: Abbay River Basin Integrated Development Master Plan Project: Data Collection - Site Investigation Survey and Analysis, Phase 2. BECOM in collaboration with BRGM and ISL Consulting Engineers, Ministry of Water Resources, Ethiopia, Addis Ababa, Ethiopia, 1998.

Saxena, R. K., Verma, K. S., Chary, G. R., Srivastava, R., and Barthwal, A. K.: IRS-1C data application in watershed characterization and management, Int. J. Remote Sens., 21, 17, 3197-3208, 2000.

Sivapalan, M.: Pattern, process and function: Elements of a unified theory of hydrology at the catchment scale, Encyclopedia of Hydrological Sciences, edited by: Anderson, M. G., John Wiley \& Sons, Ltd, 2005.

Smakhtin, V. U.: Low flow hydrology: a review, J, Hydrol., 240, 147-186, 2001.

Uhlenbrook, S.: An empirical approach for delineating spatial units with the same dominating runoff generation processes, Phys. Chem. Earth, 28, 297-303, 2003.

UMETRICS AB.: SIMCA P+ ®, Version 12.0.1.0, April, 2009.

Upton, G. and I. Cook.: A Dictionary of Statistics, Oxford University Press, London, UK, 2006.

US Department of the Interior:: Land and water resources of the Blue Nile Basin, Ethiopia, Appendixes, III, IV, and V, Bureau of Reclamation, US, 1964.

Wang, H., Meng, J., and Tenenhaus, M.: Regression Modelling Analysis on Compositional Data, in: Handbook of Partial Least Squares, edited by: Vinzi, V., Chin, W. W., Henseler, J., and Wang, H., Springer-Verlag Berlin Heidelberg, 2010.

Yadav, M., Wagener, T., and Gupta, H.: Regionalization of constraints on expected watershed response behavior for improved predictions in ungauged basins, Adv. Water Resour., 30, 17561774, 2007. 